\begin{tabular}{l|l|c}
\hline \hline Vol. 26(2):133-143 & Ocean and Polar Research & June 2004 \\
\hline \hline
\end{tabular}

\title{
Article
}

\author{
남극 세종기지에서의 구름 산란에 의한 자외선 변화 \\ 이규태 $^{1} \cdot$ 이방용 ${ }^{2 *} \cdot$ 원영인 $^{2} \cdot$ 김윤정 ${ }^{1} \cdot$ 이원학 $^{1}$ - 지준범 ${ }^{1}$ \\ 1강릉대학교 대기환경과학과 \\ (210-702) 강원도 강릉시 지변동 123 번지 \\ 2한국해양연구원 부설 극지연구소 \\ (425-600) 경기도 안산시 안산우체국 사서함 29호
}

\section{The Variation of UV Radiation by Cloud Scattering at King Sejong Station in West Antarctica}

\author{
Kyu-Tae Lee ${ }^{1}$, Bang Yong Lee ${ }^{2 *}$, Young-In Won' , Youn-Joung Kim¹, \\ Won-Hak Lee ${ }^{1}$, and Joon-Bum Jee ${ }^{1}$ \\ ${ }^{1}$ Department of Atmospheric and Environmental Sciences, Kangnung National University \\ Gangwon-do 210-702, Korea \\ ${ }^{2}$ Korea Polar Research Institute, KORDI \\ Ansan P.O. Box 29, Seoul 425-600, Korea
}

\begin{abstract}
For the purpose of understanding the cloud scattering effect of UV radiation at King Sejong station in West Antarctica, we analyzed the data measured by UV-Biometer at surface and compared its result with solar radiation model. The parameterization of UV radiation by cloud ice crystal was applied to solar radiation model and the sensitivity of this model for the variation of ice crystal was tested. The cloud optical thickness was calculated by using this solar radiation model. It was compared the result from calculation with CERES satellite data. In solar radiation model, the UV radiation was less scattered with increase of ice crystal size in cloud and this scattering effect was more important to UV-A radiation than Erythemal UV-B radiation. But scattering effects by altitude of cloud was not serious. The calculated cloud optical thicknesses in Erythemal UV-B and UV-A region were compared with CERES satellite data and the result by UV-A was more accurate than Erythemal UV-B region.
\end{abstract}

Key words : 자외선복사(UV Radiation), 산란(Scattering), 구름광학두께(Cloud Optical Thickness), 태양 복사 모형(Solar Radiation Model)

\section{1. 서 론}

태양 복사에서 자외선(UV) 영역은 파장별 흡수 특성의 변화가 크기 때문에 UV-A(320-400 nm), UV-B(280-320 $\mathrm{nm})$ 그리고 UV-C(200-280 nm)의 세 부분으로 나누어진 다. 이들 중 $\mathrm{UV}-\mathrm{C}$ 는 가장 강력한 에너지를 갖고 있기 때 문에 적은 양의 노출로도 치명적일 수 있으나, 대부분이

*Corresponding author. E-mail : bylee@kopri.re.kr
대기 상층에서 산소 원자 및 분자 등에 흡수되어 지표면 에 거의 도달하지 않는다. 그리고 $\mathrm{UV}-\mathrm{A}$ 와 UV-B는 UV-C 에 비하여 자외선 강도는 약하나 많은 양이 지표면에 도 달하기 때문에 지상 생물들에 대한 피해 효과는 작지 않 다. 특히, UV-B는 지상에 도달하여 생물의 세포 속에 있 는 DNA와 RNA를 파괴할 수 있기 때문에(Smith 1966; Rahn 1972; Parson and Gross 1980) 관심의 대상이 되고, $\mathrm{UV}-\mathrm{A}$ 는 UV-B 보다도 많은 양이 지표면까지 도달하기 때 문에 주의해야한다. 
자외선 영역의 태양 복사 에너지는 전체 태양 복사 에 너지에 비하여 그 양이 적고 대부분 대기의 상한에 도달 한 자외선이 지표면에 도달할 때까지 대기 중의 오존에 의한 흡수, 공기 분자와 에어로졸 및 구름에 의한 산란 등 에 의하여 감쇠되고, 지표면 알베도는 자외선 양에 영향을 미치는 변수이다. 이에 관한 연구로서, 구름이 없는 맑은 대기에 대하여 강릉(함 2001)과 남극 세종기지(이 등 2003)의 지표면에서 자외선 양 분석 결과가 있다. 그러나 지표면에서의 자외선 변화에, 구름에 의한 감쇠는 매우 중 요하고 이 등(2003)이 사용한 태양 복사 모형에는 이러한 구름 효과가 포함되어 있지 않다. 따라서 이 연구에서는 다양한 구름 속 빙정들에 의한 자외선 산란 과정을 모형 에 접합하였으며 자외선이 지표면에 도달하기까지 구름의 변화에 따른 모형의 반응도를 계산하였다. 또한 모형에서 계산된 자외선 양을 지표에서 관측되어진 자외선 양과 비 교하여 구름 광학 두께를 계산하였으며 이렇게 계산된 구 름의 광학 두께는 CERES(Cloud and the Earth's Radiant Energy System) 위성 자료와 비교하였다.

\section{2. 연구 자료}

이 연구에서 사용한 UV-Ameter와 UV-Biometer의 특징 들과 오존 및 에어로졸 자료 등에 관한 설명은 이 등 (2003)에 나타내어져 있다. 태양 복사 모형에 의하여 계산 된 구름의 광학 두께 결과를 비교하기 위하여 미국의 극 궤도 인공위성 CERES의 자료를 이용하였다. CERES 인 공위성의 구름 광학 두께 자료는 $0.65 \mu \mathrm{m}$ 파장에 대하여 하루 두 번 계산된 것이다. CERES 인공위성의 화소 크기 는 $1 \mathrm{~km}$ 이고 남극 세종기지를 중심으로 위·경도 $0.1^{\circ} \times$ $0.1^{\mathrm{o}}$ 범위 안에 있는 화소들의 평균 운량과 세종기지의 지

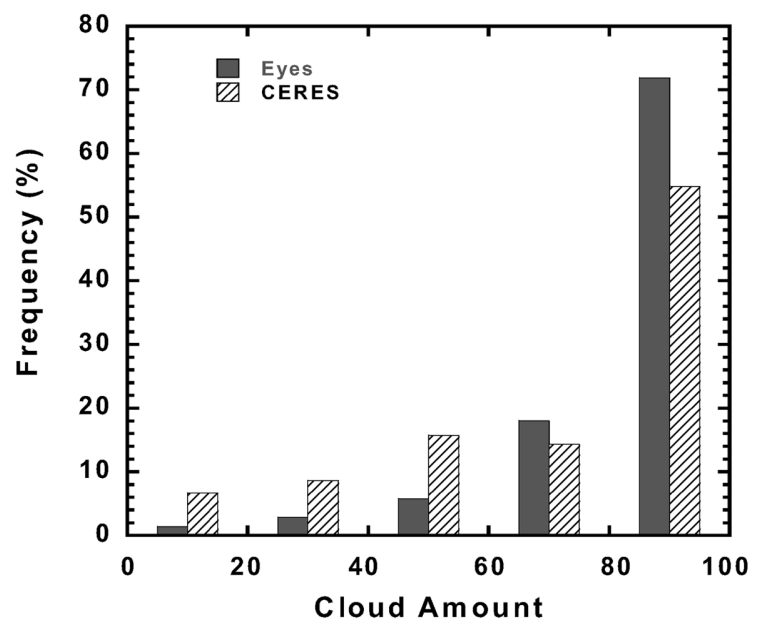

Fig. 1. Frequency $(\%)$ of daily mean cloud amount measured by eyes and CERES satellite data at King Sejong Station in West Antarctica.

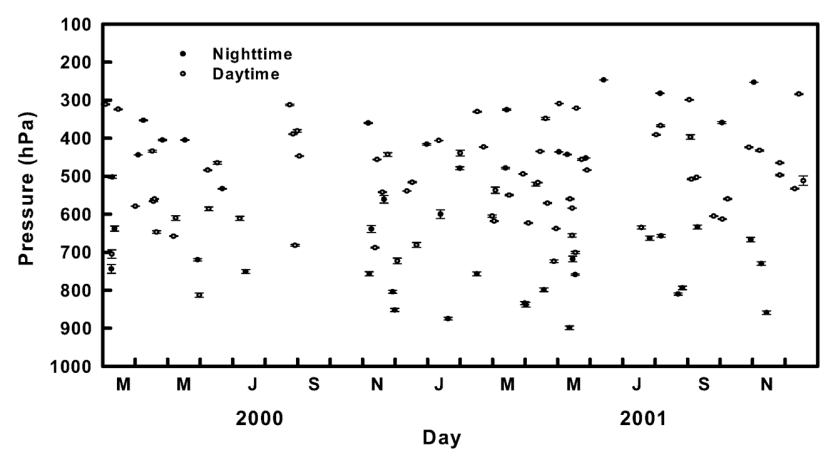

Fig. 2. Time series of cloud optical thickness and cloud top pressure in CERES satellite data from March 2000 to December 2001.

표면에서 사람이 눈으로 관측한 전운량을 Fig. 1에 나타 내었다. 사용한 기간인 2000년 3월 1일부터 2001년 12월 31 일까지 CERES 인공위성에 의한 운량 자료는 총 210 회 이었고, 이들 중에서 운량이 $80 \%$ 이상인 경우가 전체의 $54.8 \%$ 이었다. 그리고 지표면 관측의 경우는 2000년 3월 1 일부터 2001년 11월 30일까지 638일의 자료를 사용하였 고 이 자료에서 전운량이 $80 \%$ 이상인 경우는 $71.9 \%$ 이었 다. CERES 인공위성은 화소의 공간적 분해능 때문에 실 제보다 운량이 적게 평가될 수 있고 눈으로 관측할 경우 는 관측자의 시야에 따라 운량이 다소 과대평가 될 수 있 는 가능성이 있다. 따라서 남극 세종기지에서 이 연구 기 간 동안 전운량이 $80 \%$ 이상인 경우는 전제 자료의 54.8$71.9 \%$ 정도일 것으로 판단된다.

마찬가지의 기간 동안 CERES 인공위성 자료에서 전운 량이 $80 \%$ 이상일 경우 구름 광학 두께와 구름 상한의 기 압 자료를 Fig. 2에 나타내었다. 이 그림에서 보는바와 같 이 시시각각으로 변화하는 구름 광학 두께와 높이를 5 분 간격으로 정확하게 추적하는 것은 쉽지 않다. 그러나 지표 면에서의 자외선 관측 자료는 순간적으로 변화하는 구름 의 정보를 함유하고 있기 때문에 이 연구에서는 이들 지 표면에서 관측된 자외선 자료와 태양 복사 모형을 비교하 여 구름 광학 두께를 계산하였다. 그림에서 수평 바(bar) 는 구름 꼭대기의 고도를 나타내고 수직 바의 길이는 구 름 광학 두께를 나타내며 구름 광학 두께의 최대 값과 최 소 값은 각각 12.45 와 0.25 이었다. 그리고 계절별 특성은 뚜렷하지 않으며 이 계산을 위한 모형 대기의 구름 상한 은 Fig. 2의 자료 중 낮 시간에 관측된 자료들의 평균인 $513.7 \mathrm{hPa}$ 의 고도에 있는 것으로 가정하였다.

\section{3. 태양 복사 모형}

\section{태양 복사 모형}

평행 평면 대기에서 광학 두께가 $\tau_{v}$ 인 기층에서 복사 
휘도 $\left(I_{v}\right)$ 의 변화를 나타내는 일반적인 복사 전달 방정식은 다음과 같다.

$$
\mu \frac{d I_{v}\left(\tau_{v}, \mu, \phi\right)}{d \tau}=-I_{v}\left(\tau_{v}, \mu, \phi\right)+J_{v}\left(\tau_{v}, \mu, \phi\right)
$$

여기서 $\mu=\cos \theta$ 이고, $\theta$ 와 $\phi$ 는 복사의 진행 방향에 대한 천정각과 방위각이며 원천 함수 $J_{V}$ 는 다음과 같다.

$$
\begin{gathered}
J_{v}\left(\tau_{v}, \mu, \phi\right)=\frac{\omega_{v}\left(\tau_{v}\right)}{4 \pi} \int_{0}^{2 \pi} \int_{-1}^{1} d \mu^{\prime} d \phi^{\prime} P_{v}\left(\tau_{v}, \mu, \phi ; \mu^{\prime}, \phi^{\prime}\right) \\
I_{v}\left(\tau_{v}, \mu^{\prime}, \phi^{\prime}\right)+Q_{v}\left(\tau_{v}, \mu, \phi\right)
\end{gathered}
$$

식 (2)에서 $\omega_{v}\left(\tau_{v}\right)$ 는 단일 산란 알베도(single scattering albedo)이고 $P_{v}\left(\tau_{v}, \mu, \phi ; \mu^{\prime}, \phi^{\prime}\right)$ 는 위상 함수이며 $Q_{v}\left(\tau_{v}\right.$, $\mu, \phi)$ 는 열역학 평형 상태에서 원천함수이다. 모형 대기 각 기층에 대한 투과율(transmission)과 반사율(reflection) 의 계산에 있어서 직달광에 대해서는 델타-에딩턴(deltaeddington)근사(King and Harshvardan 1986)를 사용하였 고, 산란광에 대해서는 Sagan and Pollac(Lacis and Hansen 1974)의 방법을 사용하였다. 기층 간의 다중 산란에 의한 복사 속 밀도의 적분은 두 흐름 가산 근사(Lacis and Hansen 1974)를 이용하였다. 그리고 이 연구에 사용된 모 형 대기는 지표면부터 대기의 상한까지를 60 개의 기층으 로 나누었으며, 자외선 영역은 272-420 nm까지 $5 \mathrm{~nm}$ 간 격으로 분류하여 각 파장 영역 별로 지표면에 도달하는 자외선 양을 계산하였다. 또한 지구와 태양 사이의 거리 보정은 이규태 등(2003)에 나타나 있다.

\section{구름의 산란특성의 모수화}

식 (1), (2)에서 구름에 의한 산란 과정의 계산을 위하여 빙정들에 대한 단일 산란 알베도(single-scattering albedo, $\left.\omega_{\lambda}\right)$, 비 대칭 인자(asymmetry factor, $g_{\lambda}$ ) 그리고 소산 계 수(extinction coefficient, $\beta_{\lambda}$ ) 값이 필요하고 그것들은 다 음과 같이 정의된다.

$$
\begin{aligned}
& \omega_{\lambda}=\beta_{\lambda}^{s} / \beta_{\lambda} \\
& g_{\lambda}=\frac{1}{2} \int_{1}^{-1} P_{\lambda}(\mu) \mu d \mu \\
& \beta_{\lambda}=\int \sigma_{\lambda}(r) n(r) d r / C
\end{aligned}
$$

여기서 $\sigma(r)$ 은 크기가 $r$ 인 빙정의 소산 단면도(extinction cross section), $n(r)$ 은 빙정의 수, $C$ 는 구름 속 빙정의 질량 농도(mass concentration), 그리고 $P_{\lambda}(\mu)$ 는 산란 위상 함수 (scattering phase function)이다.

식 (3)-(5)의 단일 산란 특성 인자들은 파장의 함수이고 이들의 계산을 위하여 사용한 파장 영역은 Table 1 과 같이
Table 1. Spectral ranges of the solar radiation model.

\begin{tabular}{cl}
\hline Band & Spectral Range, $\boldsymbol{\mu m}$ \\
\hline 1 & $0.175-0.225$ \\
2 & $0.225-0.245 ; 0.260-0.280$ \\
3 & $0.245-0.260$ \\
4 & $0.280-0.295$ \\
5 & $0.295-0.310$ \\
6 & $0.310-0.320$ \\
7 & $0.320-0.400$ \\
\hline
\end{tabular}

0.175-0.400 $\mu \mathrm{m}$ 까지 7개의 영역으로 나누었다. Table 1의 태양 복사 파장 영역에 대한 식 (3)-(5)의 모수화를 위하여 이 연구에서는 구름 속 빙정들의 크기 분포(size distribution) 자료로서 $\mathrm{Fu}(1996)$ 와 Mitchell and Arnott(1994)의 항공기 관측 자료를 사용하였고, Yang et al.(2001)의 방법 에 따라 식 (3)-(5)를 다음과 같이 계산하였다.

$$
\begin{gathered}
\omega=\frac{\int_{L_{\min }}^{L_{\max }} \sum_{i} C_{\text {scat }, i}(L) f_{i}(L) n(L) d L}{\int_{L_{\min }}^{L_{\max }} \sum_{i} C_{\text {ext }, i}(L) f_{i}(L) n(L) d L} \\
g=\frac{\int_{L_{\min }}^{L_{\max }} \sum_{i} C_{\text {scat }, i}(L) g_{i}(L) f_{i}(L) n(L) d L}{\int_{L_{\min }}^{L_{\max }} \sum_{i} C_{\text {scat }, i}(L) f_{i}(L) n(L) d L} \\
\beta=\int_{L_{\min }}^{L_{\max }} \sum_{i} C_{\text {ext,i }}(L) f_{i}(L) n(L) d L
\end{gathered}
$$

이 식들에서 $C_{e x t}$ 와 $C_{s c a t}$ 는 평균 소산 단면도(mean extinction cross section)와 산란 단면도(scattering cross section) 이고, $n$ 은 빙정들의 수 밀도로서 $\mathrm{Fu}(1996)$ 와 Mitchell and Arnott(1994)에 의한 30종류의 빙정 크기 분포를 의미하 며, $L_{\mathrm{max}}$ 와 $L_{\mathrm{min}}$ 은 빙정들의 최대 및 최소 크기이다. 그리 고 $f_{i}$ 는 빙정의 종류와 분포를 나타내는 변수로서 이 연구 에서는 플레이트(plate), 컬럼(column), 홀로우-컬럼(hollow-column), 뷸렛-4(bullet-4), 뷸렛-6(bullet-6), 애그리게 이트(aggregate)의 6종류에 대하여 계산하였다.

식 (6)-(8)에서 $f_{i}$ 값들은 항공기 관측 자료들에 근거한 Yang et al.(2000)의 값들을 사용하였다. 즉, 그의 방법에 서 빙정의 크기가 $70 \mu \mathrm{m}$ 이하인 경우 뷸렛-4, 플레이트, 홀로우-컬럼에 대하여 $f_{i}$ 는 각각 $0.50,0.25,0.25$ 를 사용하 였고, 빙정의 크기가 $70 \mu \mathrm{m}$ 이상인 경우는 애그리게이 트, 뷸렛-4, 홀로우-컬럼, 플레이트 형태에 대하여 0.30 , $0.30,0.20,0.20$ 이다.

식 (3)-(5)에 의하여 계산된 결과들은 빙정 크기의 함수 이기 때문에 이 결과들은 Table 1 의 각 파장 영역에 대하 여 다음과 같이 분석 함수로 나타내었다. 
Table 2. Regression coefficients for $\omega$ and $g$.

\begin{tabular}{ccccccc}
\hline Band & $\boldsymbol{b}_{\mathbf{0}}$ & $\boldsymbol{b}_{\mathbf{1}}$ & $\boldsymbol{b}_{\mathbf{2}}$ & $\boldsymbol{c}_{\mathbf{0}}$ & $\boldsymbol{c}_{\mathbf{1}}$ & $\boldsymbol{c}_{\boldsymbol{2}}$ \\
\hline 1 & $6.45 \mathrm{e}-08$ & $3.46 \mathrm{e}-07$ & $-5.73 \mathrm{e}-11$ & $7.33 \mathrm{e}-01$ & $1.10 \mathrm{e}-03$ & $-4.00 \mathrm{e}-06$ \\
2 & $1.04 \mathrm{e}-07$ & $1.88 \mathrm{e}-07$ & $-1.85 \mathrm{e}-11$ & $7.44 \mathrm{e}-01$ & $1.12 \mathrm{e}-03$ & $-4.23 \mathrm{e}-06$ \\
3 & $1.07 \mathrm{e}-07$ & $1.76 \mathrm{e}-07$ & $-1.58 \mathrm{e}-11$ & $7.45 \mathrm{e}-01$ & $1.13 \mathrm{e}-03$ & $-4.24 \mathrm{e}-06$ \\
4 & $1.10 \mathrm{e}-07$ & $1.62 \mathrm{e}-07$ & $-1.28 \mathrm{e}-11$ & $7.46 \mathrm{e}-01$ & $1.13 \mathrm{e}-03$ & $-4.26 \mathrm{e}-06$ \\
5 & $1.33 \mathrm{e}-07$ & $8.12 \mathrm{e}-08$ & $3.36 \mathrm{e}-12$ & $7.55 \mathrm{e}-01$ & $1.09 \mathrm{e}-03$ & $-4.13 \mathrm{e}-06$ \\
6 & $1.37 \mathrm{e}-07$ & $7.06 \mathrm{e}-08$ & $5.64 \mathrm{e}-12$ & $7.56 \mathrm{e}-01$ & $1.08 \mathrm{e}-03$ & $-4.12 \mathrm{e}-06$ \\
7 & $1.37 \mathrm{e}-07$ & $7.06 \mathrm{e}-08$ & $5.64 \mathrm{e}-12$ & $7.56 \mathrm{e}-01$ & $1.08 \mathrm{e}-03$ & $-4.12 \mathrm{e}-06$ \\
\hline
\end{tabular}

$$
\begin{aligned}
& 1-\omega=b_{0}+b_{1} D_{e}+b_{2} D_{e}^{2} \\
& g=c_{0}+c_{1} D_{e}+c_{2} D_{e}^{2} \\
& \beta=a_{0}+a_{1} / D_{e}
\end{aligned}
$$

이 식들에서 $1-\omega, g, \beta$ 는 7개 파장 영역 대한 각각 단 일 산란 코-알베도, 비 대칭 인자 및 소산 계수이다. 그리 고 $a$ 와 $b$ 및 $c$ 는 회귀 계수들이며, $D_{e}$ 는 유효 입자 크기 (effective particle size)로서 산란체의 직경을 의미한다. 이들 회귀 계수들의 값들 중에서 파장 영역에 따른 변화 가 거의 나타나지 않는 소산 계수에 대한 회귀 계수 $\left(a_{0}=3.33 e-04, a_{1}=3.27 e+00\right)$ 를 제외한 $b, c$ 를 Table 2 에 나타내었다. 빙정의 단일 산란 특성은 빙정의 유효 입 자 크기에 따라 변화한다. 따라서 Table 1의 7개의 파장 영역에 대하여 식 (9)-(11)에 의한 단일 산란 코-알베도와 비 대칭 인자 및 소산 계수를 계산하였다. 단일 산란 코알베도는 (1-단일 산란 알베도)로서, 그 값이 작을수록 단 일 산란 알베도는 1 에 가까운 값을 갖게 된다.

Fig. 3은 소산 계수를 나타낸 것으로서, 모든 파장 영역 에 대해 지수 함수적으로 급속히 감소한다. 즉, 빙정의 유 효 입자 크기가 $20 \mu \mathrm{m}$ 미만일 경우는 소산 계수가 약 0.16-3.3 m $\mathrm{m}^{2} \mathrm{~g}^{-1}$ 까지 변화하고, 빙정의 유효 입자 크기가 $150 \mu \mathrm{m}$ 로 증가하면 $0.02 \mathrm{~m}^{2} \mathrm{~g}^{-1}$ 정도의 값을 갖는다. 이는 주어진 체적 내의 빙정 입자가 클수록 태양 복사의 소산 효과가 적음을 나타내는 것이다. 이처럼 빙정의 유효 입자 크기가 $80 \mu \mathrm{m}$ 이상이 되면 소산 계수가 급격히 감소하는 데 그 이유는 이 부분에서 태양 복사에 대해서 다음 식과 같이 소산 효율(extinction efficiency, $Q_{e}$ )이 크게 감소하기 때문이다.

$$
Q_{e}=\frac{\int_{L_{\min }}^{L_{\max }} Q_{e}(L) A(L) n(L) d L}{\int_{L_{\min }}^{L_{\max }} A(L) n(L) d L}
$$

이 식에서 $A(L)$ 은 빙정 크기에 따른 소산 단면적을 의미 하고, 소산 효율 $\left(Q_{e}\right)$ 은 각각의 파장 영역에 대하여 소산

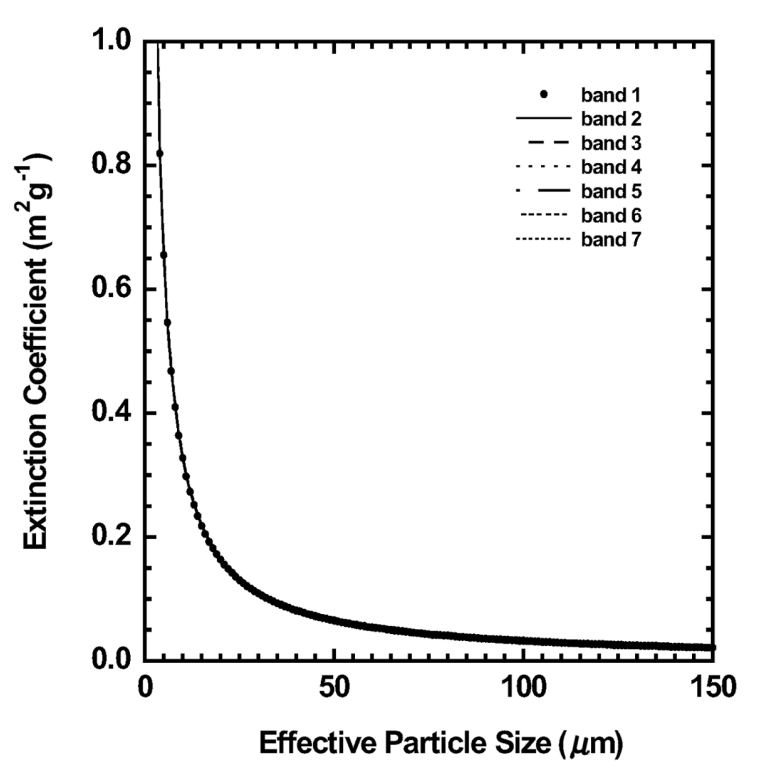

Fig. 3. The extinction coefficient as a function of the effective particle size for bands 1-7.

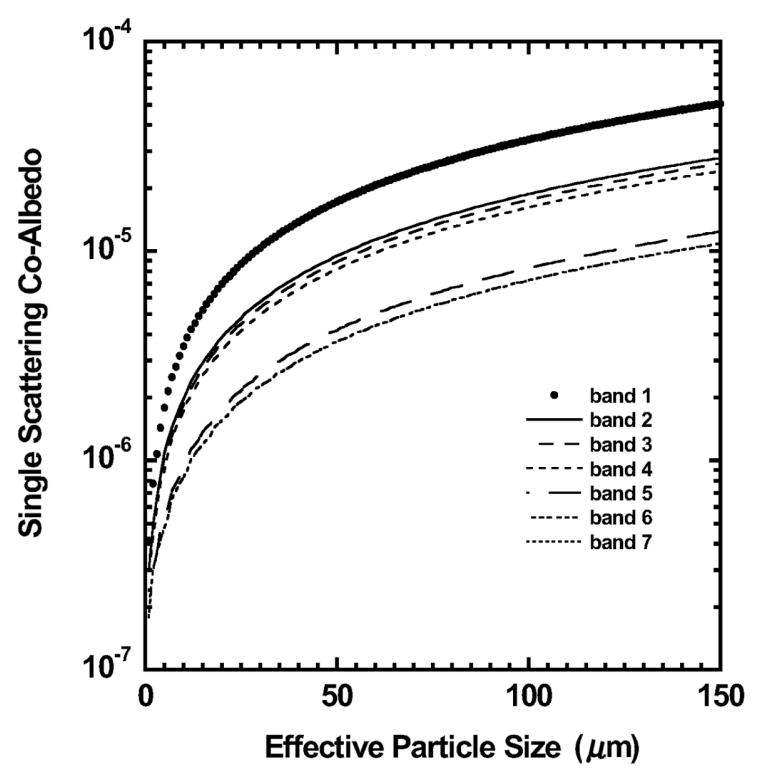

Fig. 4. Same as Fig. 3, except for the single scattering co-albedo. 


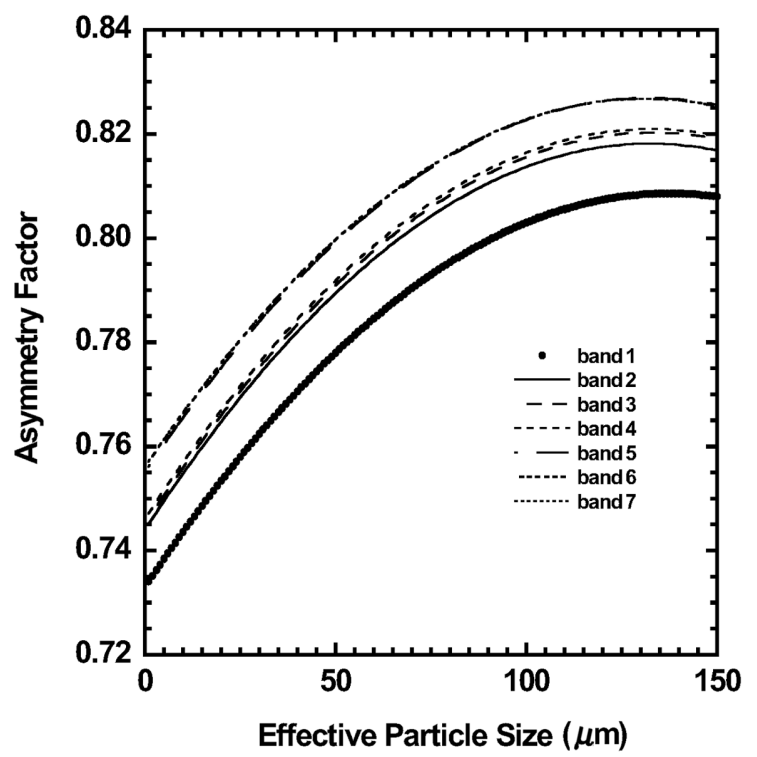

Fig. 5. Same as Fig. 3, except for the asymmetry factor.

계수 $(\beta)$ 와 다음과 같은 관계를 가진다.

$$
\beta=\frac{3}{2} \frac{Q_{e}}{\rho_{\text {ice }} D_{e}}
$$

여기서 $\rho_{i c e}$ 는 빙정의 밀도를 의미한다.

Fig. 4는 7개 파장 영역에 대한 단일 산란 코-알베도 값 으로 7개 파장 영역 모두에서 $10^{-4}$ 이하로서 매우 작은 값 을 갖는다. 따라서 식 (9)에 따라 이 연구에서는 단일 산란 알베도 값을 1 로 가정하였다.

Fig. 5는 비 대칭 인자를 나타낸 것이다. 빙정의 유효 입자의 크기가 증가할수록 포물선 형태의 비 대칭 인자들 의 값이 나타나고 있다. 그 이유는 식 (12)와 같이 소산 효율의 변화 때문이다. 또한 7 개의 파장 영역에 따라 비 대칭 인자의 값들이 변화하고, 파장이 작은 부분에서 작 은 값을 나타내는 것을 볼 수 있다. 즉, 지표면 자외선 복 사량의 계산시 빙정 구름의 비 대칭 인자가 매우 중요함 을 알 수 있다.

\section{4. 결과 및 토의}

\section{태양 복사 모형의 반응도}

이 연구에서 사용된 태양 복사 전달 과정의 모수화는 Chou and Lee(1996)에 근거하였으며, UV-A(320-400 nm) 와 UV-B(280-320 nm)의 파장 영역에 대하여 지표면에서 의 자외선 양을 계산하였다.

지표에 도달하는 자외선이 대기 중의 오존에 의한 흡 수, 공기 분자와 에어로졸 및 구름에 의한 산란 등에 의하 여 감쇠되므로, 따라서 이론적인 모형에 의하여 지표면에
도달하는 자외선 양을 계산하기 위해서는 다음의 과정을 거친다. 즉, 위도와 시간의 변화에 따른 태양의 천정각 및 지구와 태양의 거리 효과 계산, 그리고 대기 중에서 오존 에 의한 흡수 효과와 공기 분자 및 에어로졸 그리고 구름 에 의한 산란 효과 계산 과정이 필요하다. 이들 중에서 대 기 외 일사량은 $175-400 \mathrm{~nm}$ 의 파장 영역에 대하여 위성 에서 관측된 0.1-0.3 nm의 간격의 자료를 2-5 nm 간격으 로 다시 적분하여 71 개의 자료로 만들어 사용하였고 결과 는 이 등(2003)에 나타낸 바 같다.

일반적으로 공기 입자들에 의한 복사의 흡수는 기압과 기온의 함수이나 오존 흡수 계수는 기압과 기온의 영향이 매우 작기 때문에 오존의 연직 분포의 변화는 크게 중요 하지 않다. 따라서 이 연구에서는 오존전량 관측 값을 아 극 겨울철 표준 대기(U. S. Air Force 1976)의 오존 연직 분포에 따라 비례적으로 계산하여 사용하였다. 에어로졸 은 세종기지 상공의 자료가 없기 때문에 McMurdo 기지 의 자료를 근거로 $340 \mathrm{~nm}$ 에서 연직 공기 기둥에 대한 에 어로졸의 광학 두께를 0.1 로 가정하였으며, 에어로졸의 단 일 산란 알베도와 비 대칭 인자는 각각 0.999 와 0.610 을 사용하였다. 지표면 알베도는 남극 세종기지에서 계절별 변화가 크기 때문에 남반구 겨울철은 0.85 를 그리고 여름 철은 0.20 으로 가정하였고 봄과 가을은 이들을 내삽하여 월별 변화를 가정하였다(Roger 2002). 이상과 같은 태양 복사 모형의 입력 자료 이외에 태양상수는 $1365 \mathrm{Wm}^{-2}$ 그 리고 이산화탄소는 $350 \mathrm{ppmv}$ 를 사용하였고 입력 자료들 에 대한 자외선 양의 반응도를 계산하였다. 이 중에 오존 전량, 에어로졸, 지표면 알베도에 대한 반응도의 결과는 이 등(2003)에 나타낸 것과 같다.

구름의 산란에 따른 자외선 양의 변화 계산을 위하여 오존은 $250 \mathrm{DU}$, 에어로졸의 광학 두께는 0.1 , 지표면 알 베도는 0.5 를 가정하였다. 그리고 구름 속의 빙정은 그 직 경을 $46 \mu \mathrm{m}$ 로 가정하였고 이 구름은 모형 대기의 288$311 \mathrm{hPa}$ 고도에 존재하는 것으로 가정하였다. 이 경우 구 름의 광학 두께가 1 부터 30 까지 변화할 때 지표면에서의 자외선 변화를 Fig. 6에 나타내었다. 이 그림에서, 태양 천 정각의 코사인 값이 0.3 일 경우 구름 광학 두께가 1 에서 30 으로 증가하면서 UV-A는 $66.3 \%$, Erythemal UV-B는 $61.9 \%$ 감소하였다. 또한 태양 천정각의 코사인 값이 0.9 일때는 각각 $64.2,61.8 \%$ 감소하여 지표면에 도달하는 자 외선은 구름 광학 두께에 따라 크게 변화하는 것을 알 수 있다.

구름이 존재하는 고도 변화에 따른 자외선 양의 변화를 계산하기 위하여 구름 광학 두께가 10 인 구름의 고도를 200 부터 $800 \mathrm{hPa}$ 까지 변화시켰고 이때 지표면에서의 자 외선 반응도는 Fig. 7 에 나타내었다. 그 결과 태양 천정각 의 코사인 값이 0.6 인 경우 UV-A와 Erythemal UV-B는 

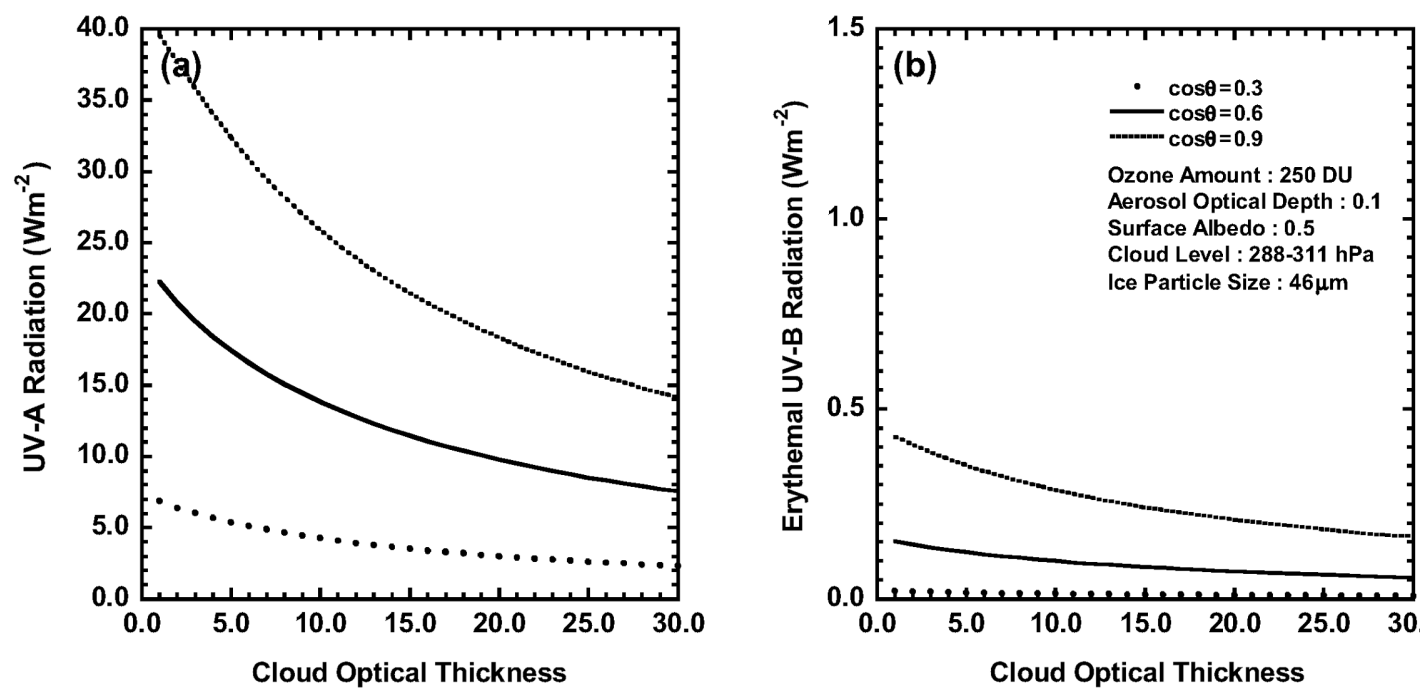

Fig. 6. Sensitivity of UV-A radiation (a), and Erythemal UV-B radiation (b) to cloud optical thickness by solar radiation model.
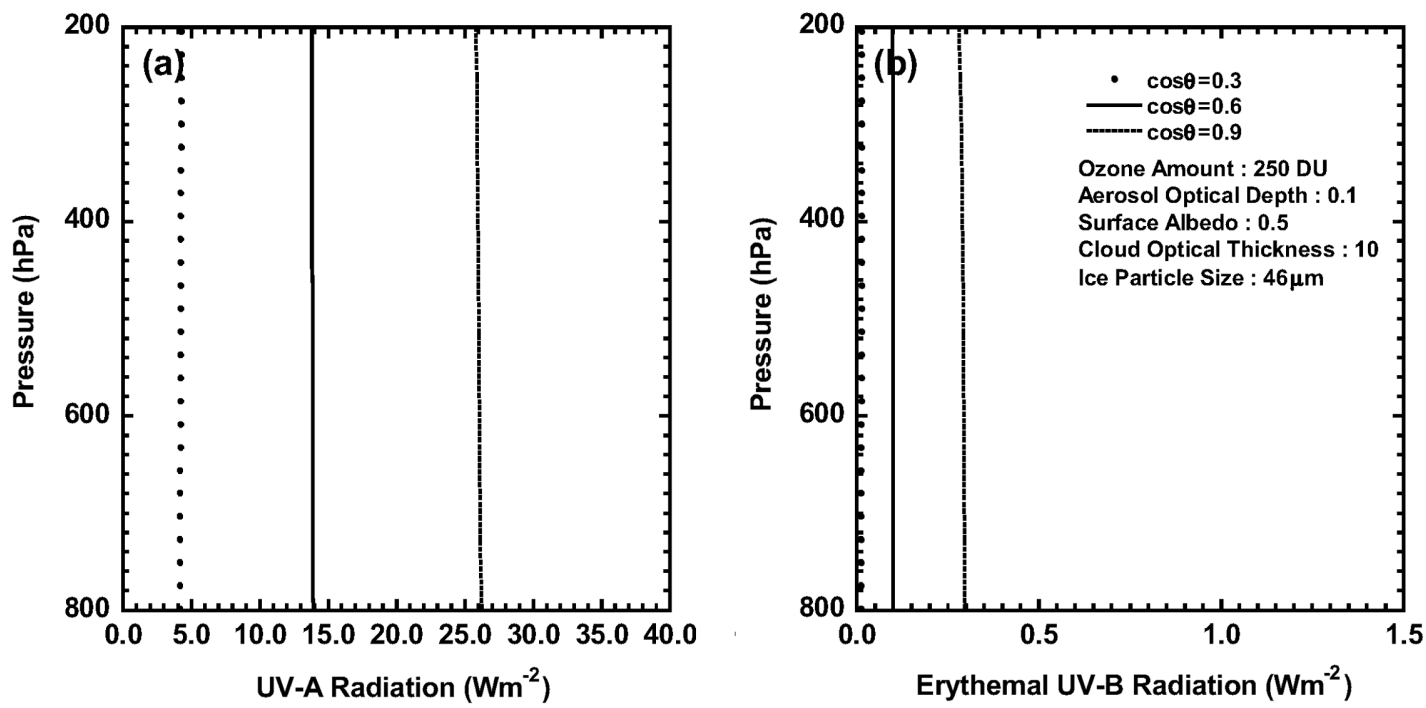

Fig. 7. Same as Fig. 6, except for altitude of cloud.

각각 $0.6,2.0 \%$ 감소를 나타내었다. 즉, UV-A와 Erythemal $\mathrm{UV}-\mathrm{B}$ 모두 구름의 고도에 따른 변화는 크지 않음을 알 수 있다. 왜냐하면 구름 고도 변화에 대하여 빙정들의 산란 특성 변화가 없고 UV-A와 Erythemal UV-B는 오직 지 표면과 구름 층 간의 다중 산란에 의하여 변화하기 때문 이다.

빙정의 직경에 따른 자외선 변화는 Fig. 8에 나타내었 다. 이 그림에서 구름의 광학 두께는 10 그리고 고도는 288-311 hPa로 가정하였다. 태양 천정각의 코사인 값이 0.3 인 경우에 빙정의 직경이 5 에서 $150 \mu \mathrm{m}$ 까지 변화할 때, 지표면에 도달하는 UV-A와 Erythemal UV-B 자외선 은 각각 $14.3,13.3 \%$ 증가하였고, 태양 천정각의 코사인이
0.9 인 경우에는 각각 $14.0,12.8 \%$ 증가하였다. 즉, 구름 속 의 빙정 질량이 일정한 상태에서 빙정의 크기가 증가할수 록 자외선의 산란 효과가 작게 나타나고, 이 산란 효과는 Erythemal UV-B 보다 UV-A가 크게 나타났다. Erythemal $\mathrm{UV}-\mathrm{B}$ 는 UV-A 보다 오존에 의한 자외선의 감쇠가 크게 나타나기 때문에 구름 속 빙정의 산란에 의한 자외선의 감쇠 효과가 UV-A 보다 작게 나타나는 것이다.

남극 세종기지의 지표면에서 자외선 양과 구름 광학 두께

남극 세종기지에서 2000년 3월부터 2001년 12월까지 관측된 UV-A 및 Erythemal UV-B 자료와 태양 복사 모델 에 의한 계산 결과들 중에서 비교적 구름 없는 맑은 날 

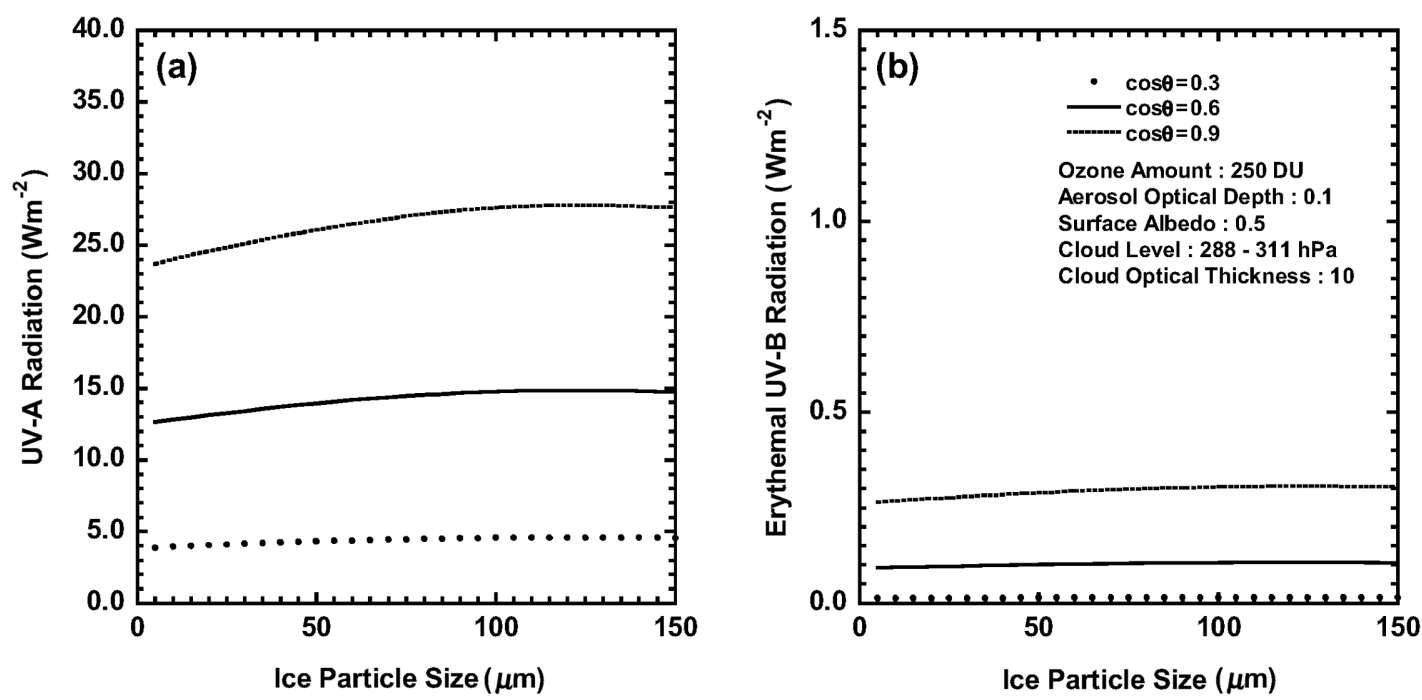

Fig. 8. Same as Fig. 6, except for ice particle size.
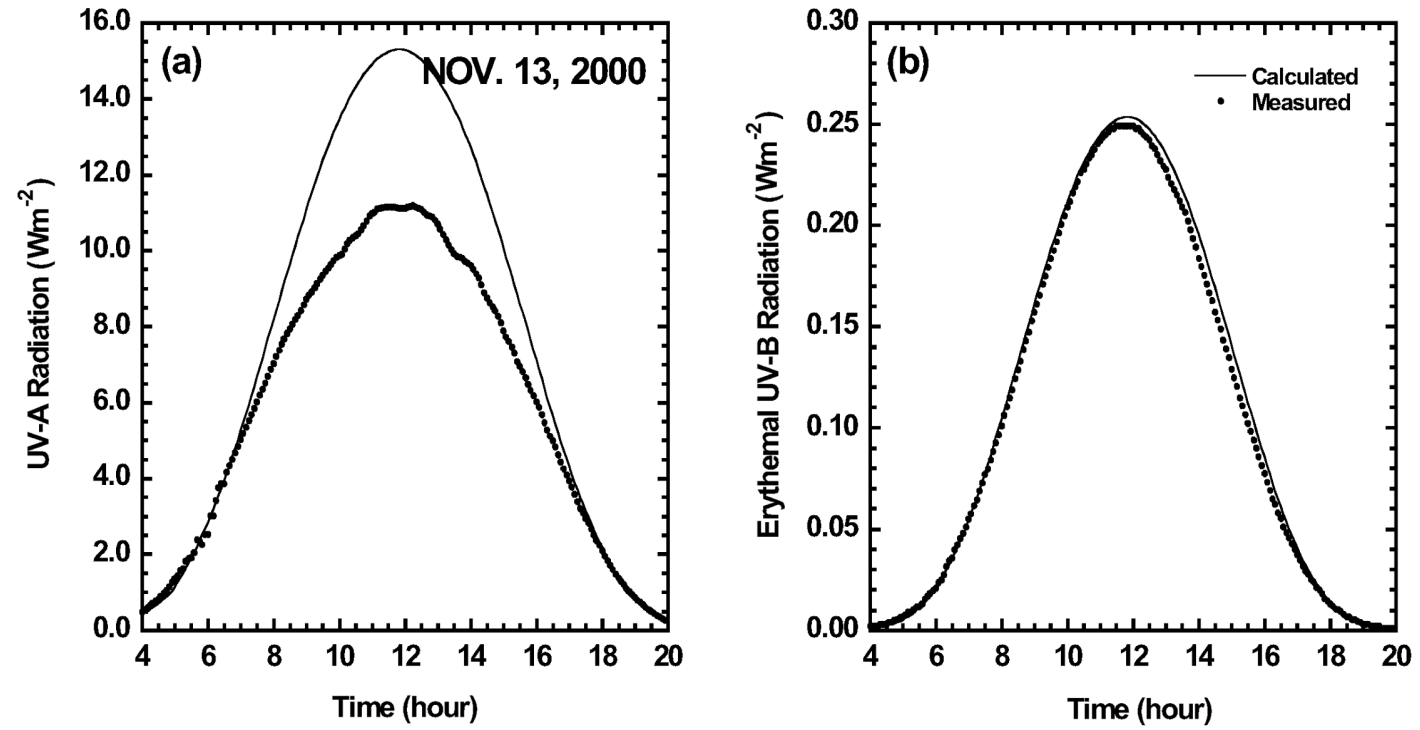

Fig. 9. The measured and calculated UV-A (a) and Erythemal UV-B radiation (b) under relatively clear sky.

(2000년 11월 13 일)의 경우 매 5분 동안의 평균 자외선 강 도 $\left(\mathrm{Wm}^{-2}\right)$ 를 Fig. 9에 나타내었다. 이 그림에서 태양 복사 모형에 의하여 계산된 지표면에서의 자외선 양은 구름 효 과를 전혀 포함시키지 않은 것으로서 Erythemal UV-B의 관측 값과 잘 일치하고 있으나, 12시 이후는 옅은 구름 때 문에 계산 값은 관측 값과 차이가 있음을 알 수 있다. 그 러나 같은 날 UV-A는 계산 값과 관측 값 사이에 최대 $4.1 \mathrm{Wm}^{-2}$ 의 차이가 있었다. 즉, Erythemal UV-B는 오존 량에 따라 크게 변화하는 반면 옅은 구름 효과는 크지 않 기 때문에 계산 값과 관측 값이 잘 일치하였고, 이 결과 만으로 평가한다면 오전은 매우 맑은 상태이며 오후가 되 면서 약간의 옅은 구름이 존재하는 것으로 판단된다. 그러
나 UV-A는 대기 중의 구름 영향을 크게 받기 때문에 이 그림에서 보는 바와 같이 8 시부터 18 시까지 옅은 구름이 존재하는 것을 알 수 있다.

Fig. 10은 Fig. 9에 비하여 구름이 더 많이 존재하는 경 우(2000년 11월 16일)로서, 태양 복사 모형에 구름 효과 를 포함하여 관측 값과 비교한 것이다. 이 경우에 구름은 CERES 인공위성 자료의 평균 기압 고도인 $513.7 \mathrm{hPa}$ 과 빙정의 직경 $46 \mu \mathrm{m}$ 를 가정하였다. 이 그림에서 관측과 계 산된 자외선 강도의 최대 차이는 UV-A와 Erythemal UV$\mathrm{B}$ 의 경우 각각 1.0 과 $0.002 \mathrm{Wm}^{-2}$ 미만이었다. 특히, 13 시 와 17 시 사이에는 비교적 두꺼운 구름이 세종기지 상공을 지나갔는데 이 경우 계산된 최대 구름 광학 두께는 UV-A 

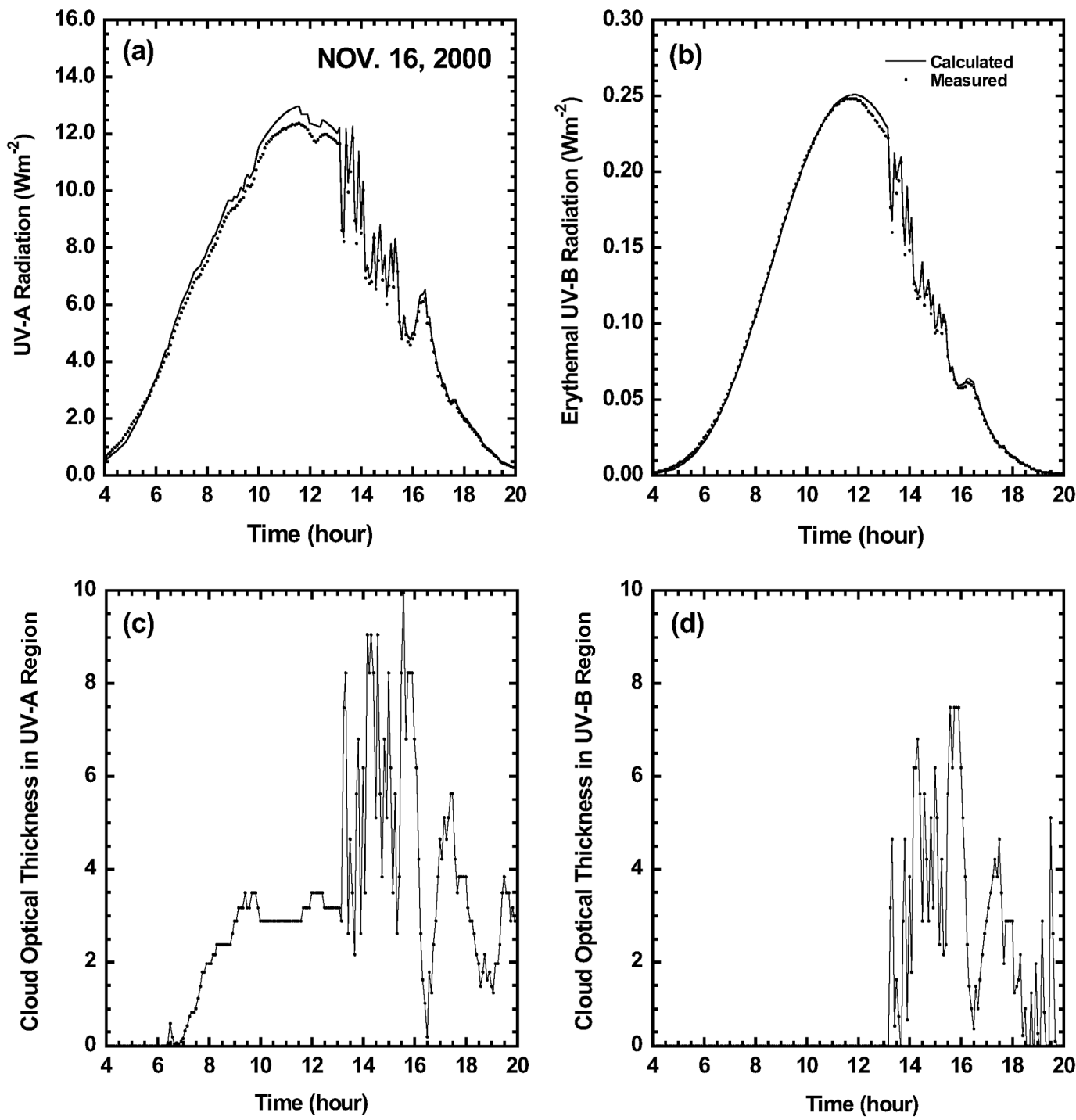

Fig. 10. The measured and calculated UV-A (a) and Erythemal UV-B radiation (b) under relatively cloud sky. And the cloud optical thickness calculated by solar radiation model in the UV-A (c) and Erythemal UV-B (d) region.

와 Erythemal UV-B 영역의 경우 각각 10.0 과 7.5 이었으 며, 오전 중에 지나간 옅은 구름의 최대 구름 광학 두께는 UV-A와 Erythemal UV-B 영역의 경우 각각 3.5 와 0.0 이 었다. 이 그림에서와 같이 구름의 광학 두께는 UV-A와 Erythemal UV-B 파장 영역에 대하여 서로 다른 값을 나 타내는데, Erythemal UV-B 파장 영역에서는 구름 광학 두께에 대하여 UV-A 파장 영역에서 보다 민감하지 못하 기 때문에 구름 광학 두께 값이 작게 계산된다.

이 연구 기간 동안 세종기지에서 관측된 UV-A 자외선 의 일 누적 값 $\left(\mathrm{kJm}^{-2}\right)$ 과 계산 값의 차이를 Fig. 11 에 나타 내었다. 이 그림에서 (a)는 일 누적된 UV-A 자외선으로서 계절별 변화가 뚜렷하게 나타난다. 남극의 겨울철에는 지 표면에 도달하는 자외선 양이 매우 적기 때문에 구름이
있는 날과 없는 날의 구별이 뚜렷하지 못하다. 그러나 여 름철에 비교적 구름 없는 맑은 날은 구름 있는 날보다 지 표면에 도달하는 UV-A 자외선 양이 약 4배까지 증가한 다. 그리고 태양 복사 모형에 의하여 계산된 결과는 관측 값에 비하여 여름철에 최대 약 $12.8 \mathrm{kJm}^{-2}$ 로 $3.6 \%$ 정도 크게 나타나고, 남반구 늦은 겨울철 또는 이른 봄철에 가 끔 계산 값이 작게 나타나는 경우는 모형 속에 포함된 지 표면 알베도 값의 부정확성 때문이라고 판단된다.

Erythemal UV-B의 경우는 Fig. 12에 나타내었다. 이 경 우도 Fig. 11과 마찬가지로 지표면에 도달하는 Erythemal UV-B의 관측 값은 계절별 변화가 뚜렷하고, 태양 복사 모 형에 의하여 계산된 값은 관측 값에 비하여 여름철에 $0.3 \mathrm{kJm}^{-2}$ 로 $4.3 \%$ 크게 나타난다. 그러나 이 경우는 계절 


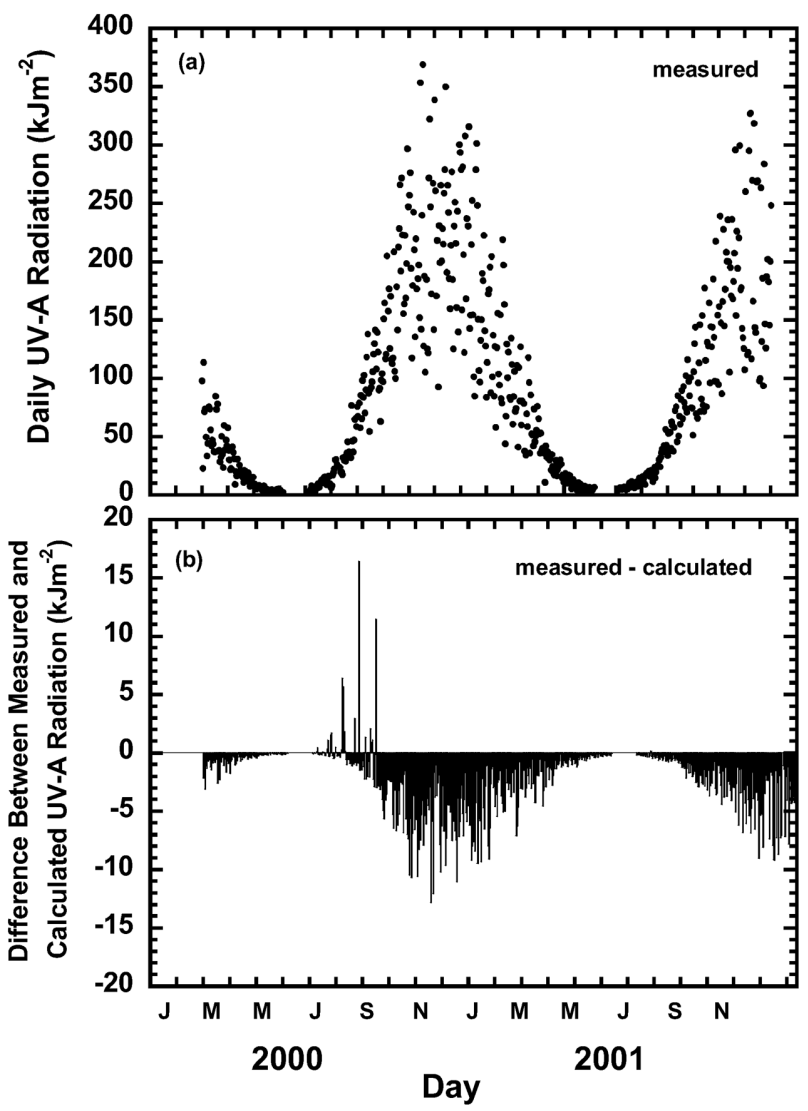

Fig. 11. The daily sum of measured UV-A radiation (a), and the difference between measured and calculated value (b).

에 상관없이 계산 값이 관측 값보다 작은 경우가 발생되 는데, 이는 태양 복사 모형의 입력 자료로 가정하여 사용 한 오존량의 부정확성이 주 원인이라고 생각된다. 그러나 세종기지에 오존관측 시스템이 잘 구축되어있는 만큼 좀 더 축적된 현지의 자료를 사용하게 되면 이러한 부정확성 의 문제는 개선될 수 있을 것이다.

Fig. 11과 12에서 계산된 구름 광학 두께의 일평균 값은 Fig. 13에 나타내었다. 이 그림에서 (a)는 UV-A 영역에 대 한 것으로서 구름 광학 두께는 최대 96.5 이었고, 이 연구 기간 동안 총 평균 구름 광학 두께는 16.2 이었으며, 지표 면에 도달하는 UV-A 자외선 양과 마찬가지로 계절별 변 화를 보였다. (b)의 경우는 Erythemal UV-B 영역에서 계 산된 구름 광학 두께로서 최대 96.1 이고 평균 14.9 로서 UV-A 영역에 비하여 구름 광학 두께가 작게 나타나며, 그 이유는 Fig. 12에서 설명한 바와 같이 역시 가정된 오존 자료의 부정확성 때문이라고 본다. 따라서 UV-A 영역에 서의 구름 광학 두께와 같이 계절별 변화가 뚜렷하게 나 타나지 않고 있다.

태양 복사 모델을 통해 계산된 구름 광학 두께 값을

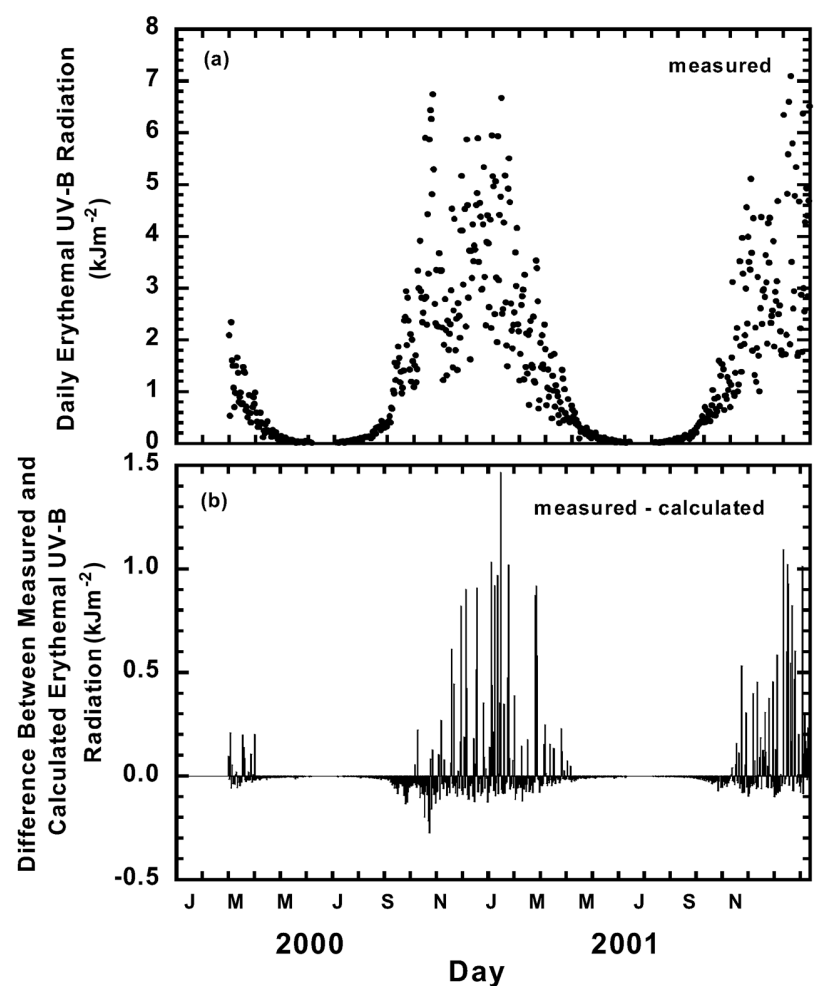

Fig. 12. Same as Fig. 11, except for Erythemal UV-B radiation.
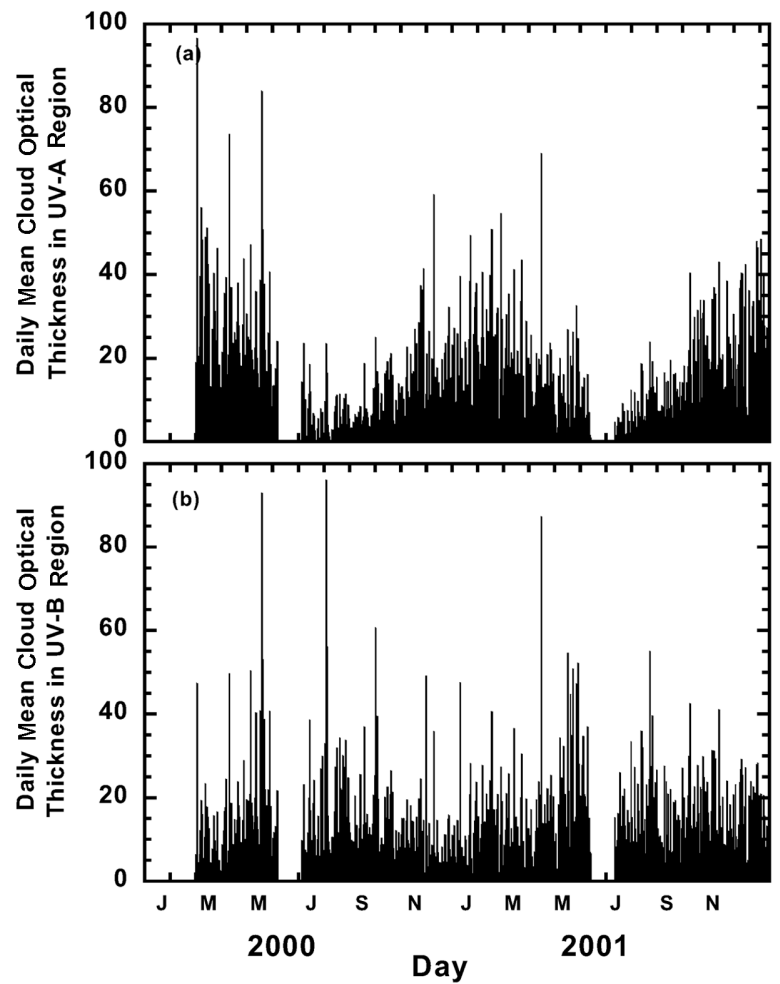

Fig. 13. Daily mean cloud optical thickness by solar radiation model in UV-A (a) and Erythemal UV-B (b) region. 

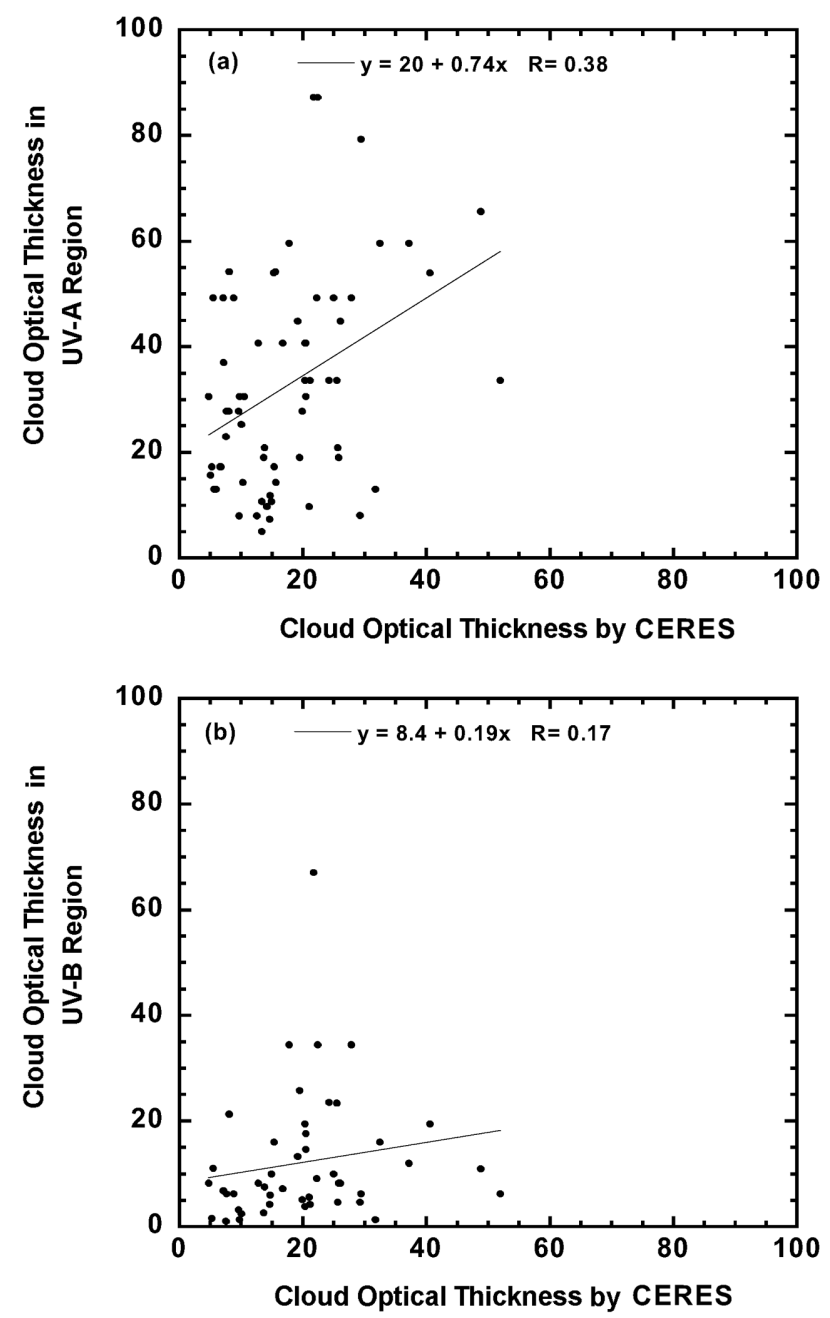

Fig. 14. The relationship between cloud optical thickness in CERES satellite data and calculated by solar radiation model in UV-A (a) and Erythemal UVB (b) region.

CERES 위성 자료와 비교하였고 그 결과는 Fig. 14와 같 다. CERES 인공위성은 일출 시간 부근에 세종기지를 통 과하고, 이 시간에 지표면에 도달하는 자외선 양은 매우 적다. 따라서 이 시간에 계산된 구름 광학 두께는 정확하 지 않을 수 있다. 특히 UV-Biometer는 UV-Ameter 보다 자외선에 대한 관측 기기의 반응도가 작기 때문에 CERES 인공위성이 세종기지 상공을 통과할 때 UV-A 보다 상대 적으로 자외선 양이 적게 관측된다. 따라서 이 그림 (a)에 서처럼 UV-A 영역에 대한 구름 광학 두께는 CERES 인 공위성 자료와 비하여 0.38 의 상관관계를 나타내는 반면, (b)에서처럼 Erythemal UV-B 영역의 경우는 상관관계가 0.17 에 불과하다. UV-A와 Erythemal UV-B 영역의 경우 에 이와 같이 낮은 상관관계는 앞에서 설명한 바와 같이 CERES 인공위성이 일출 직후 세종기지를 통과하기 때문
으로 태양의 고도가 높아질수록 이 연구에서 계산된 구름 광학 두께 계산 결과의 정확성이 높아질 것이다.

\section{5. 결 론}

남극 세종기지에 대하여 적용할 목적으로 구름 속 빙정 관측 자료에 근거하여 태양 복사 모형을 구축하였고, 이 결과는 세종기지의 지표면에서 관측된 자외선 양과 비교 하였다. 그리고 이 과정에서 계산된 구름 광학 두께는 CERES 위성 자료와 비교 분석하였다.

비교적 구름 없는 맑은 날의 경우 이 연구에서 사용한 태양 복사 모형에 의하여 지표면에 도달하는 Erythemal UV-B 자외선 양을 비교적 정확하게 계산할 수 있었다. 그 러나 UV-A는 약간의 옅은 구름 또는 에어로졸에 대하여 민감하게 반응하기 때문에 관측 결과와 비교할 경우 조심 스럽게 취급해야한다.

구름은 시시각각으로 모양과 광학 두께 및 고도가 변화 하므로 시간 변화에 따른 이들 구름의 효과를 정확하게 태양 복사 모형에 적용하기는 쉽지 않다. 이 연구에서 사 용된 태양 복사 모형의 입력 자료로서, 구름의 고도는 CERES 위성 자료 중 구름 정상 기압을 평균하여 사용하 였다. 그리고 이 모형에 의하여 세종기지에서의 자외선 양 계산 결과와 직접 관측된 자외선 양을 비교하여 구름 광 학 두께를 계산하였다.

남극의 겨울철에는 지표면에 도달하는 자외선 양이 매 우 적기 때문에 구름이 있는 날과 없는 날의 구별이 뚜렷 하지 못하나, 여름철에 비교적 구름 없는 맑은 날은 구름 있는 날 보다 지표면에 도달하는 UV-A 자외선이 약 4배 까지 증가한다. 그리고 태양 복사 모형에 의하여 계산된 결과는 관측 값에 비교하여 여름철에 최대 $12.8 \mathrm{kJm}^{-2}$ 로 $3.6 \%$ 정도 크게 나타났다. 또한 Erythemal UV-B의 경우 는 모형에 의한 계산 값이 여름철에 $0.3 \mathrm{kJm}^{-2}$ 로 $4.3 \%$ 크 게 나타났고, 태양 복사 모형에서 오존량의 입력 자료의 부정확성 때문에 관측 값과의 오차가 UV-A 보다 크게 나 타났다.

태양 복사 모형에 의하여 계산된 구름 광학 두께 값을 CERES 위성 자료와 비교하였다. CERES 인공위성은 세 종기지의 일출 시간 부근에 통과하고, 이 시간에 지표면에 도달하는 자외선 양은 매우 적기 때문에 계산된 구름 광 학 두께는 정확성이 떨어진다. 특히 UV-Biometer는 UVAmeter 보다 자외선에 대한 관측 기기의 반응도가 작기 때문에 CERES 인공위성이 세종기지를 통과할 때 UV-A 보다 상대적으로 자외선 양이 적게 관측된다. 따라서 UV$\mathrm{A}$ 영역에 대한 구름 광학 두께는 CERES 인공위성 자료 와 비교하여 0.38의 상관관계를 나타내고 Erythemal UV$\mathrm{B}$ 영역의 경우는 상관관계가 0.17 이었다. 그러나 일출 직 
후 또는 일몰 직전의 낮은 태양 고도에서는 UV-Biometer 와 UV-Ameter 관측 값의 정확성이 떨어지고, 평행 평면 대기를 가정하는 태양 복사 모형의 계산 값 오차도 마찬 가지로 증가할 수 있다. 태양의 고도가 증가하면서 이러한 관측 및 계산의 오차 발생 요인이 줄어들기 때문에 이 연 구에서 계산된 구름 광학 두께 계산 결과의 정확성은 높 아질 것이다. 다만, CERES는 궤도 위성으로서 매일 비슷 한 시간에 세종기지 상공을 통과하기 때문에 다양한 태양 고도 각에 따른 구름 광학 두께 자료를 생산하지 못한다 는 것이 아쉽다.

\section{사 사}

이 연구는 한국해양연구원 부설 극지연구소의 ‘지구대 기 연직구조별 대기환경 특성 및 빙하연구(PP03105)'사업 과 ‘북극 대기환경 및 광물자원 연구(PN51200)' 사업의 지원을 받아 수행되었다. 이 논문의 향상을 위해 조언해주 시고 심사하여 주신 심사위원들께 감사드린다.

\section{참고문헌}

이규태, 이방용, 원영인, 지준범, 이원학, 김윤정. 2003. 대기 복사 모형에 의한 남극 세종기지에서의 복사학적 특징: 지표면에서 UV-A와 Erythemal UV-B 자외선 양 변화. Ocean Polar Res., 25, 9-20.

함길주. 2001. 성층권 오존량 변화에 따른 강릉지방의 지표 면에서 UV-A와 UV-B의 변화. 강릉대학교 교육대학원 석사학위논문. $36 \mathrm{p}$.

Chou, M.D. and K.T. Lee. 1996. Parameterization for the absorption of solar radiation by water vapor and ozone. J. Atmos. Sci., 53, 1203-1208.

$\mathrm{Fu}$, Qiang. 1996. An accurate parameterization of solar radiative properties of cirrus for climate models. J. Climate, 9, 2058-2082.

King, M.D. and Harshvardan. 1986. Comparative accuracy of selected multiple scattering approximations. J. Atmos. Sci., 43, 784-801.

Lacis, A.A. and J.E. Hansen. 1974. A parameterization for the absorption of solar radiation in the earth's atmosphere. J. Atmos. Sci., 31, 118-133.

Mitchell, D.L. and W.P. Arnott. 1994. A model predicting the evolution of ice article size spectra and radiative properties of cirrus clouds, Part II: ependence of absorption and extinction on ice crystal morphology. J. Atmos. Sci., 26, 138-147.

Parson, P.C. and P. Gross. 1980. DNA damage and repair in human cell exposed to sunlight. Photochem. Photobiol., 32, 635-641.

Rahn, R.O. 1972. Ultraviolet irradiation of DNA. p. 2-53. In: Concepts in radiation cell biology. ed. by G.L. Whitson. Academic Press.

Roger, A. Pielke. 2002. Mesoscale Meteorological Modeling. Second Edition, Academic Press. 676 p.

Smith, K.C. 1966. Physical and chemical changes induced in neucleic acids by ultraviolet light. Radiant. Res. Suppl., 6, 54-79.

U.S. Air Force. 1976. U. S. Standard Atmosphere, U.S. Air Force. 227 p.

Yang, P., K.N. Liou, K. Wyser, and D. Mitchell. 2000. Parameterization of the scattering and absorption properties of individual ice crystals. J. Geophys. Res., 105, 46994718.

Yang, P., B.C. Gao, B.A. Baum, W. Wiscombe, Y.X. Hu, S.L. Nasiri, P.F. Soulen, A.J. Heymsfield, G.M. McFarquhar, and L.M. Miloshevich. 2001. Sensitivity of cirrus bidirectional reflectance to vertical homogeneity of ice crystal habits and size distribution for two MODIS bands. J. Geophys. Res., 106, 17267-17291. 